О. М. Хвисюк, В. Г. Марченко, О. М. Касьянова, І. А. Соболєва, О. А. Цодікова, 3. В. Єлоєва, О. І. Сергієнко, К. І. Бодня, В. В. Жеребкін, М. П. Гиря Харківська медична академія післядипломної освіти

\title{
ІНСТИТУЦЙНИЙ РОЗВИТОК ВИЩОГО МЕДИЧНОГО НАВЧАЛЬНОГО ЗАКЛАДУ ЯК ОСНОВА ЗАБЕЗПЕЧЕННЯ ЯКОСТІ ВИЩОЇ МЕДИЧНОЇ ОСВІТИ
}

\author{
O. M. Khvysiuk, V. H. Marchenko, O. M. Kasianova, I. A. Sobolieva, O. A. Tsodikova, \\ Z. V. Yeloieva, O. I. Serhiienko, K. I. Bodnia, V. V. Zherebkin, M. P. Hyria \\ Kharkiv Medical Academy of Postgraduate Education

\section{INSTITUTIONAL DEVELOPMENT OF HIGHER EDUCATION INSTITUTIONS AS A BASIS FOR QUALITY ASSURANCE IN HIGHER MEDICAL EDUCATION}

\begin{abstract}
Мета роботи - висвітлення й обгрунтування досвіду Харківської медичної академії післядипломної освіти щодо використання власного ресурсного потенціалу та факторів зовнішнього середовища для інституційного розвитку і забезпечення якості післядипломної медичної освіти.

Основна частина. Представлена діяльність ХМАПО щодо організації ефективної взаємодії з об'єктами зовнішнього середовища, забезпечення попиту на освітні послуги, створення інформаційно збагаченого освітнього середовища, нарощування ресурсного потенціалу та створення гнучкої системи управління.

Такі інституційні зміни зумовили необхідність розробки, обговорення та затвердження цільового проекту розвитку ХМАПО, реалізація якого забезпечить отримання позитивного результату та характеризує перехід навчального закладу на вищий щабель діяльності.

Висновок. Інституційні зміни виявляються у підвищенні кваліфікації персоналу, творчій реалізації освітніх завдань, у повному використанні ресурсного потенціалу, залученні додаткових ресурсів.
\end{abstract}

Ключові слова: інституційний розвиток ВНЗ; якість післядипломної медичної освіти; програмно-цільовий підхід; інформаційно збагачене середовище; корпоративне підвищення кваліфікації; кваліметричний моніторинг; технологія поелементного аналізу; портфоліо слухача.

The aim of the study - to present the experience of Kharkiv Medical Academy of Postgraduate Medical Education in resource potential and environmental factors usage for capacity building and postgraduate medical education quality providing.

The main body. Activity of KhMAPE as the organization of effective interaction with objects in the external environment is represented. It includes providing demand for educational services, the creation of educational environment that enriched with information, increasing resource potential and creation of a flexible management system. These institutional changes have caused the necessity of the development, discussion and approval of the project target of KhMAPE. Its realization is going to provide discovery and characterize up-coming transition of educational institution.

Conclusion. The institutional changes are manifested in staff development, creative implementation of educational objectives, full use of the resource potential, the attraction of additional resources.

Key words: institutional development of universities; the quality of postgraduate medical education; program and target approach; information-rich environment; corporate advanced training; qualimetrical monitoring; technology of element analysis; participant's portfolio.

Вступ. Необхідність забезпечення вищими навчальними закладами якості освітньої діяльності і якості вищої освіти закріплено Законом України “Про вищу освіту” (2014) [1]. Проте зацікавленість проблемами якості освіти зумовлена низкою чинників, а саме:

(ㄷ О. М. Хвисюк, В. Г. Марченко, О. М. Касьянова та ін.
- підвищення якості освіти є необхідною умовою формування інформаційного суспільства та конкурентоспроможної економіки, що зумовлені стрімкими й динамічними цивілізаційними змінами;

- актуалізація проблем якості освіти пов'язана із концептуалізацією нової моделі фахівця - особистості, яка здатна до саморозвитку, самоосвіти, 
до співпраці у межах відкритого полікультурного освітнього і професійного середовища, вміє гнучко використовувати власний освітній ресурс, приймати самостійні, відповідальні рішення;

- критерієм якісної освіти є не сукупність певних знань, умінь, навичок та життєвих компетенцій випускника ВНЗ, а здатність особистості генерувати нові ідеї, вирішувати нетипові професійні й життєві ситуації, сформованість мислення, спрямованого на майбутнє, ціннісних орієнтацій, що відповідають сучасним реаліям;

- криза освітньої сфери, що засвідчує її нездатність вирішувати нагальні проблеми і зумовлює необхідність пошуку нових можливостей та перспектив розвитку, рефлексії набутого педагогічного досвіду у світлі сучасних освітніх тенденцій [2].

Зазначені вище обставини спонукають не лише до переосмислення діяльності вищого навчального закладу, а й передбачають його розвиток як інституції, що історично обумовлений і визначається ресурсним середовищем самого закладу, залежить від його адаптаційної спроможності, діяльності управлінського та педагогічного персоналу, можливості поєднання різноспрямованих інституційних змін, забезпечується теоретико-методологічним обгрунтуванням педагогічних феноменів, застосуванням інноваційних видів освітньої практики.

Мета роботи - висвітлення й обгрунтування досвіду Харківської медичної академії післядипломної освіти щодо використання власного ресурсного потенціалу та факторів зовнішнього середовища для інституційного розвитку і забезпечення якості післядипломної медичної освіти.

Основна частина. Дослідження містить три взаємопов’ язані концепти, які зумовлюють реалізацію його провідної мети: методологічний концепт включає фундаментальні концепції щодо реформування медичної та освітньої галузей; теоретичний орієнтує на використання наукового підгрунтя для інституційного розвитку організації; технологічний включає опис конкретних дій навчального закладу з вирішення окресленої проблеми.

За А. Туреном, інституція має позначати не те, що було інституційовано, а те, що є джерелом інституціювання, тобто ті механізми, завдяки яким культурні орієнтири трансформуються в соціальну практику [3].

Отже, інституційний розвиток вищого навчального закладу передбачає: 1) ефективну взаємодію з чималою кількістю різних об’єктів зовнішнього середовища (органи влади, партнери, конкуренти, громадські організації, засоби масової інформації, слухачі тощо); 2) забезпечення попиту на освітні послуги; 3) створення інформаційно збагаченого освітнього середовища; 4) ефективне використання та нарощування ресурсного потенціалу організації; 5) створення гнучкої системи управління.

Загальновідомо, що будь-яка людська діяльність здійснюється на основі уявлення про бажаний результат, шляхи його досягнення й необхідні для цього засоби. Отже, інноваційні зміни, що відбуваються у навчальному закладі, є результатом раціонально організованих процесів реалізації оптимальними шляхами і методами поставлених цілей.

Відтак, для вирішення найважливіших, найактуальніших проблем використовується програмно-цільовий підхід, який грунтується на їх комплексному аналізі та побудові системної сукупності дій і заходів, спрямованих на досягнення поставленої мети, вирішення цільового завдання, що виокремлюється 3 аналізованих проблем.

Використовуючи програмно-цільовий підхід, Харківською медичною академією післядипломної освіти розроблено і успішно реалізується маркетингова стратегія просування власних освітніх послуг, розширення їх спектра шляхом вивчення ситуації, узгодження з потребами ринку, пошуку ділових партнерів, замовників освітніх послуг та реалізація стратегії через оволодіння викладачами новітніми інтерактивними, індивідуалізованими, командними та проектними технологіями, що включають питання фандрейзингу, процедури подання запитів на державну підтримку та грантові конкурси.

Модернізація усіх сфер життєдіяльності українського суспільства зумовлює необхідність переосмислення якості післядипломної медичної освіти. Це, у свою чергу, вимагає якісно нового рівня надання освітніх послуг закладами післядипломної освіти та створення умов для ефективного, продуктивного навчання фахівців. Результатом такого навчання має стати високий рівень їхньої професійної компетентності, яка визначається ступенем відповідності теоретичних знань та умінь їх практичному використанню у житті і професійній діяльності при розвитку потреб людини у постійному оновленні своїх знань та умінь і неперервним їх удосконаленням.

Такий навчальний процес вимагає змін у професійно-педагогічній діяльності викладача та навчально-пізнавальній діяльності слухача. Для викладача - це перехід від викладання до супро- 
воджуючого навчання, від монологу до взаємодії, від подання готової інформації до дослідного навчання, від оцінки рівня засвоєння знань, умінь, навичок слухачами до визначення рівня їх компетентності. Для слухача - це перехід від сприйняття і запам’ятовування навчальної інформації до усвідомленого, активного навчання, від зовнішньої до внутрішньої мотивації, від знань до компетенцій.

Отже, у Харківській медичній академії післядипломної освіти на заміну моделі навчання, в центрі якої знаходиться викладач, а слухачі пасивно засвоюють інформацію, приходить нова модель навчання, заснована на таких методологічних засадах: в центрі технології навчання - слухач; в основі навчальної діяльності - співробітництво; провідний метод - інтерактивний, слухачі відіграють активну роль у навчанні; сутність технології - розвиток здатності слухачів до самонавчання.

Незаперечною є думка, що післядипломна освіта має забезпечувати інтелектуалізацію інформаційного освітнього простору, створення нового інформаційного поля, що збагатить навчальне середовище та зумовить задоволення освітніх потреб висококваліфікованим фахівцям, професійна діяльність яких необхідна для сталого розвитку суспільства.

Необхідність створення інформаційно збагаченого освітнього середовища вимагає запровадження дистанційного навчання.

Дистанційне навчання як нова педагогічна технологія в системі післядипломної медичної освіти допомагає інтегрувати різноманітні можливості мережі “Інтернет” у навчальний процес, запровадити новітні методи і технології, що відповідають телекомунікаційному середовищу.

Проте при запровадженні дистанційного навчання у ХМАПО на перший план ставилось не впровадження техніки, а відповідне змістове наповнення циклів тематичного удосконалення та інших освітніх послуг.

При виокремленні тем лекцій, семінарських і практичних занять, що виносяться на дистанційне навчання, використовувалися такі критерії відбору:

- потреби та інтереси слухачів (визначали за результатами анкетування і тестування слухачів);

- складність навчального матеріалу (розраховували на засадах закону Бредфорда, показника інформаційно-знаннєвих елементів навчального тексту, показників труднощів навчального матеріалу, а саме: інформативність, абстрактність навчальних понять і складність їх структури (І. Підласий, Т. Канівець, Л. Лутченко));
- при визначенні тем семінарів і практичних робіт виходили із можливостей обговорення питань та контролю виконання у віртуальному режимі.

Реалізація дистанційного навчання у ХМАПО забезпечує отримання слухачем знань у процесі розв’язання змістових завдань, попередньо розроблених викладачем із використанням програмнопедагогічних засобів, що надаються шляхом організації мережевого доступу до серверних ресурсів навчального закладу.

3 метою нарощування ресурсного потенціалу в Академії створена система корпоративного підвищення кваліфікації персоналу. Так, для забезпечення практики активного володіння науковопедагогічними працівниками Академії мовами проводяться цикли тематичного удосконалення 3 англійської та української мов, організовано систематичну роботу Speaking-Club. Започатковано проведення в режимі on-line для науково-педагогічних працівників Академії навчально-демонстраційних сесій з української мови.

Щорічно проводяться олімпіади з англійської мови серед інтернів та конкурс знавців англійської мови серед науково-педагогічних працівників.

Запроваджено практику участі іноземних клінічних ординаторів - носіїв англійської мови - у навчальному процесі циклів тематичного удосконалення з іноземних мов.

Створений оновлюваний освітній портал із набуття і підтримки науково-педагогічними працівниками Академії англомовної компетентності. На порталі розміщуються тестові модулі, на підставі яких визначається рівень опанування науково-педагогічними працівниками англійської мови для цілеспрямованого формування індивідуальних маршрутів навчання та здійснення самоаналізу успішності оволодіння іншомовними компетенціями, е-посібники, відеоуроки, завдання для самостійного опрацювання, презентації, автентичні тексти, аудіозаписи тощо.

За результатами щорічних рейтингових досліджень узагальнюється та оприлюднюється ефективний досвід роботи кафедр Академії, що увійшли у топ-10 найкращих кафедр, та перспективний педагогічний досвід викладачів.

Складовою системи управління якістю післядипломної медичної освіти є створений в Академії підрозділ забезпечення якості освіти, що здійснює аналітико-експертну діяльність, на підставі якої надає своєчасну, релевантну, об’єктивну інформацію для ефективних управлінських рішень. Моніто- 
рингові дослідження є головним інструментарієм контролю за основними індикаторами статичної та динамічної моделей результативності діяльності підрозділів Академії, її ресурсного потенціалу та інституційного розвитку.

На підгрунті особливостей освітнього моніторингу, його місця в управлінській діяльності визначено такі основні напрями його здійснення в Академії: 1) моніторинг контексту освітнього процесу; 2) моніторинг ресурсів освітнього процесу; 3) моніторинг перебігу освітнього процесу; 4) моніторинг результатів освітнього процесу.

Моніторинг створює інформаційну систему, що передбачає безперервність відстеження перебігу процесів та отримання результатів, а також включає розробку апарату та технологій вимірювання існуючого стану об’єкта, процесу або явища.

Одним із підходів, що використовується для здійснення моніторингових досліджень в Академії, є кваліметричний підхід. Він грунтується на найголовніших принципах кваліметрії: урахування взаємозв’ язку між складними і простими властивостями об’єктів через створення стандарту відповідної моделі ідеального об’єкта (або якості об’ єкта) шляхом декомпозиції для виділення основних параметрів його розвитку [4].

Моніторинг якості післядипломної медичної освіти здійснюється також на основі технології поелементного аналізу, в основу якої покладено змістовно-діяльнісний підхід, що грунтується на таксономії цілей Б. Блума, та тестово-операціональний підхід В. Беспалька. Ця технологія моніторингових досліджень якості післядипломної

\section{Список літератури}

1. Закон України “Про вищу освіту” // Відомості Верховної Ради (ВВР). - 2014. - № 37-38. - Ст. 2004.

2. Ганаба С. Мережеві технології як складова якісної освіти / Світлана Ганаба // Вища школа. - 2016. - № 1. C. 44-52.

\section{References}

1. Zakon Ukrainy "Pro vyshchu osvitu” [ Higher Education Act of Ukraine]. (2014, July 1). Vidomosti Verkhovnoi Rady Ukrainy - Bulletin of Verkhovna Rada of Ukraine. Kyiv: Parlam. vyd-vo [in Ukrainian].

2. Hanaba, S. (2016). Merezhevi tekhnolohii yak skladova yakisnoi osvity [Network technologies as part of high quality education]. Vyshcha shkola - Higher school, 1, 44-52 [in Ukrainian]. медичної освіти позитивно зарекомендувала себе у практиці навчання на циклах тематичного удосконалення ХМАПО.

Забезпеченню якості освітніх послуг, що надає Академія, сприяє здійснення самомоніторингу системної цілеспрямованої роботи з оцінювання власних навчальних досягнень слухачами шляхом запровадження портфоліо, що містить самоаналіз професійної діяльності, самооцінку рівня оволодіння знаннями, уміннями, навичками, рефлексію навчальних занять, відомості про заходи, у яких брав участь слухач під час навчання на циклі ТУ, та їх успішність тощо.

Отже, інституційні зміни передбачають методологічне, теоретичне підгрунтя розробки та реалізації цільового проекту розвитку організації, що спрямований на модернізацію діяльності як окремих працівників, так і навчального закладу у цілому. Зростання вищого навчального закладу інституційно виявляється у підвищенні кваліфікації персоналу, творчій реалізації освітніх завдань, у повному використанні ресурсного потенціалу, залученні додаткових ресурсів.

Висновок. Інституційний розвиток ВМНЗ передбачає наявність інноваційних механізмів, що створюються безпосередньо в управлінському, педагогічному і виробничому процесах, міститься в отриманому позитивному результаті та характеризує перехід навчального закладу на вищий щабель діяльності.

Перспективи подальших досліджень полягають у визначенні інноваційних механізмів інституційного розвитку ВМНЗ та розробки технологій їх широкого використання.

3. Турен А. Повернення дієвця / А. Турен. - К. : Альтерпрес, 2003. - С. 19.

4. Марченко В. Г. Моніторинг якості післядипломної освіти на основі кваліметричного підходу : навч.-метод. посіб. / В. Г. Марченко, О. М. Касянова. - Х. : ХМАПО, 2013. - 76 с.

3. Turen, A. (2003). Povernennia diievtsia [Return of doer]. Kyiv: Alterpres [in Ukrainian].

4. Marchenko, V.H., \& Kasianova, O.M. (2013). Monitorynh yakosti pisliadyplomnoi osvity na osnovi kvalimetrychnoho pidkhodu [Monitoring of the quality of postgraduate education based on qualimetric approach]. Kharkiv: KhMAPO [in Ukrainian]. 